\title{
Development of Prediction Regression Equations for Biomass Estimation in Eucalyptus Forest Plantations in the Punjab State of India
}

\author{
Deepak Kholiya, Rakesh Chandra Bhadula, Amit Kumar Mishra, Ajay Sharma, Satyajeet Singh
}

\begin{abstract}
Prediction equations have been worked out on the basis of 17 trees felled for Eucalyptus hybrid for different tree components on the basis of diameter and height $\left(D^{2} H\right)$ which was found to be best suited as depended variable over $D \& D^{2}$ (Diameter at Breast Height $1.37 \mathrm{~m}$ ). The correlation coefficient $\left(r^{2}\right)$ values of all the tree components are significant where as these values for AGB (Above Ground Biomass), BGB (Below Ground Biomass) and Total Biomass (TB) is highly significant. These developed prediction equations are validated by comparing the predicted values of total biomass of overall average trees felled with their actual / calculated biomass. The differences of predicted and actual biomass ranged from 6.8 to $38.5 \%$ of different diameter classes in the felled Eucalyptus trees. Generally differences between predicted and actual biomass in percentages of $10-30 \%$ is universally acceptable in forest management.
\end{abstract}

Key Words: Eucalyptus tree, Prediction equation, Diameter class, Biomass etc.

\section{INTRODUCTION}

Eucalyptus(under Family: Myrtaceae) is a versatile tree that can be grown almost anywhere. This is traditionallypropagated through seeds thus rendering plants with wide variation in bole girth and height. Generally in a seed raised monoculture plantations, one-fourth plants are above average, one fourth below average and about half are of average quality and volume. The clonal technology has covered such drawbacks and given a tremendous potential to manifold increase in productivity and significant improvement in uniformity and quality of wood. Traditionally Eucalyptus is grown as boundary plantation as compared to block plantation. Higher productivity of clonal planting material encouraged farmers to take up block plantation of Eucalyptus. It has been observed that farmers give better management to clonal plantations than for seedling origin. The main reason behind this is higher initial cost of clonal material (Rs. 10-12/plant) in comparison to seedlings (Rs. $1.0-2.0$ / plant). The tree characteristics such as fast growing nature, straight stem, self-pruning, clear bole and narrow crown suits well for its adoption as a potential agroforestry tree in this region.

Revised Manuscript Received on August 10, 2019.

Deepak Kholiya, Department of Agriculture, Graphic Era Hill University, Dehradun.

Rakesh Chandra Bhadula, Department of Mathematics, Graphic Era Hill University, Dehradun.

Amit Kumar Mishra, Department of Computer Science \& Engineering, Graphic Era Hill University, Dehradun.

Ajay Sharma, Department of SOM Graphic Era Hill University, Dehradun.

Dr Satyajeet Singh, Department of Mathematics, Graphic Era Deemed to be University, Dehradun.
Eucalyptus plantation started in India since 1960s in various parts of the country. Apart from 107 species and provenance tried in India, E. tereticornis (E. hybrid), E camaldulensis, E. grandis, E. globulus and E. citriodora were considered to be the best suited to Indian conditions.In recent years the Eucalyptus, which has dominated the scene in various parts of the country, has attained the fame as Eucalyptus hybrid or Mysore gum / Blue gum / Safeda. It is considered to be the only Eucalyptus, which has very wide adaptability under different edaphic conditions right from seacoasts to high hills (both in tropical and temperate zones) and from low to fairly high rainfall areas (Qureshi, 1966). Its origin in India is traced to the Eucalyptus which has been planted on the Nandi hills in the state of Karnataka (erstwhile Mysore) a long time ago and thus of Mysore origin. The name of Eucalyptus hybrid is most frequently used by foresters in India (Rawat, 1996). Momolli, D et al. (2019) devolved a mathematical modeling for Eucalyptus biomass quantification in Brazil. The study was carried out in the Eucalyptus saligna 10-year-old trees for determination of biomass by felled 12 trees and quantified leaves, branches, bark and wood was estimated seperately. The total biomass was $269 \mathrm{Mg} \mathrm{ha}^{-1}$, of which $89 \%$ was wood. The total volume was 546 and $494 \mathrm{~m}^{3} \mathrm{ha}^{-1}$ with and without bark, representing an average annual increase of 54,6 and $49,4 \mathrm{~m}^{3} \mathrm{ha}^{-1}$ year $^{-1}$. This type of the modeling presents excellent adjustments and certainly serves for future estimates of the forest plantations stock biomass for trees species especially. It is estimated that over $3 \%$ of the net sown area in Punjab has come under Eucalyptus (Dogra\&Sandhu, 1984). E. hybrid has been planted in India in almost every state for large scale afforestation and plantation programmes both to cover denuded and barren areas as well as for converting poor or derelict forest growth into fast growing monocultures of high productivity (Qureshi, 1966). In Punjab E. hybrid was planted extensively during the 1980 s on forests along roadsides, canals and drains. The species has been found to be quite suitable for plantations on semi-arid tracts (Dogra and Upadhyay, 2005).

\section{EXPERIMENTAL STUDY SITE}

Eucalyptus hybrid species planted at different five study sites of Punjab Forest Division Located in:1. Patiala(Site:T.E.C.Patiala),2.Ludhiana(Site:- 
Doraha), 3. Hoshiarpur (Site:-Dholbaha, Katour and Kharkan) 4. Amritsar(Site:- Kamalpur - I and Kamalpur II) and 5. Faridkotforest division. It includes in the various Agro-climatic zones of Punjab as follows:-

\subsection{Agro-Ecoregion (2) Western Plain Hot Arid Ecoregion}

The agro-ecoregion (2) includes Ferozepur, Faridkot, Bhatinda, Muktsar, Fazilka, Mansa western part of Rajasthan (Marusthal), southwestern part of the states of Haryana and Punjab, the kutch peninsula and northern part of Kathiawar peninsula. It covers an area of $29.6 \mathrm{~m}$ ha., representing 9.0 per cent of the total geographical area of the country.

The region represents typic hot-arid climate which is charateristised by hot summers and cool winter with mean and annual precipitation of less than $300 \mathrm{~mm}$. it covers about 20 per cent of mean annual potential evaportranspiration (PET) which ranges between 1500 and $1900 \mathrm{~mm}$. this results in large annual water deficit of 1500$1800 \mathrm{~mm}$ in the area. The area represents acidic soil moisture and hyperthermic soil temperature regime with an annual growing period (GP) of less than 90 days.

The dominant soil-scapes, representing the area, are gently to very gently sloping Torripsamments, canborthids and Calciorthids interspersed with level to very gently sloping salorthids and Natrargids. The dominant sandy soils, represented by Thar series (Torripsamments), are moderately calcareous and alkaline in reaction.

The natural vegetation comprises sparse, sporadic tropical thorn forest. Rainfed agriculture is the traditional practice followed by the farmers. They grow drought-resistant and short-duration rainy season crops. Like pearlmillet, chari (fodder), sorghum and pulses in non-saline areas, the yield of these crops is low under average management practices.

\subsection{Agro-Ecoregion (4)Northern Plain and Central Highlands, Hot Semiarid Ecoregion}

The agro-ecoregion (4) constitutes Amritsar, Kapurthala, Ludhiana, Patiala, Sangrur, Moga, Jalendhar parts of northern plain, Central Highlands and Gujarat Plain. It covers an area of $32.9 \mathrm{~m}$ ha., representing 19.0 per cent of the total geographical area of the country. The climate of the region is characterised by hot and dry summers and cool winters. The annual precipitation is the region ranges between 400 and $800 \mathrm{~mm}$ with an increasing trend from west to east. It covers 40 per cent of the mean annual potential evaportranspiration (PET) which ranges between 1400 and $1900 \mathrm{~mm}$. the area shows an annual water deficit of $700-1000 \mathrm{~mm}$. the moisture availability (growing) period ranges between 90 and 150 days. The soil moisture regime is uatic while the soil temperature regime is hyperthermic.

The soil-scapes in the region vary from moderately to gently sloping, coarse to fine loamy, Ustochrepts and Haplustalfs, grading through gently to very gently sloping Ustochrepts, and Ustipsamments, to nearly level Ustifluvants. In the northern part of the region, the terrain is frequently interspersed by sand-dunes. The soils of the region are partly representd by Chomu, Kanjli and ZarifaViran series. The Chomu and Kanjli soils are sandy and coarse loamy while the ZarifaViranSiols are fine loamy and highly sodic in nature.

The natural vegetation comprises tropical dry deciduous and tropical thorn forests. Rainfed farming is the normal practice followed in the region. However, tin the northern plain, the farmers have overcome the droughty climate by introducing tubewell irrigation at critical stages of crop growth. The irrigated areas are intensively cultivated for both kharif and rabi crops, such as rice, millets, maize, pulses, berseem, wheat and mustard and also for sugarcane.

\subsection{Agro-Ecoregion (9)Northern Plain and Central Highlands, Hot Semiarid Eco-region}

The agro-ecoregion (9) covers a Gurdaspur, Hoshiarpur, Garhshankar, Nawanshahr, Ropar, Fatehgarh Sahib a part of the northern Indo-Gangetic Plain of the western Himalayas. The region occupies an area of $12.2 \mathrm{~m}$ ha., representing 3.7 per cent of the total geographical area of the country.

The climate of the region is characterised by hot to warn summers and cool winter. The region receives mean annual rainfall of 1000 to $1200 \mathrm{~mm} ; 70$ per cent of which is realized during the summer monsoon period (July to September). The rainfall covers abut 70 per cent of the annual potential evapotranspiration (PET) of 1400 to 1800 $\mathrm{mm}$ and leaves an annual water deficit of 500 to $700 \mathrm{~mm}$. the region has a moisture availability (growing) period of 150 to 180 days in a year. The region experiences dry period from February to June and mean annual temperature of more than $22^{\circ} \mathrm{C}$, and thus qualifies for ustic soil moisture and hyperthermic soil temperature regime. The areas adjacent to foothills are relatively cooler and experience thermic soil temperature regime.

The soils of the region are generally deep. Loamy and have developed on alluvium. The dominant soil-scapes that represent the northern plain constitute gently to very gently sloping Ustochrepts, Haplustalfs and Ustifluvents. The areas adjacent to foothills of the Western Himalaysa (Tarai Zone) are dominated by soil-scapes of moderately to gently sloping Hapludolls and Hapludalfs. The moisture availability in these soils ranges from medium to high. The Basiaran and Haldi Series represents the soil of the plains and of the piedmont plain, respectively; the latter are rich in organic matter content.

The natural vegetation in the region comprises tropical moist deciduous dry deciduous forests. Depending on the availability of water resources, the traditional farming practices followed in the area comprise both rainfed and irrigated agriculture. The common crops grown are: rice, maize, pigeonpea and jute (in Kharif Season), and wheat (in Rabi season) 


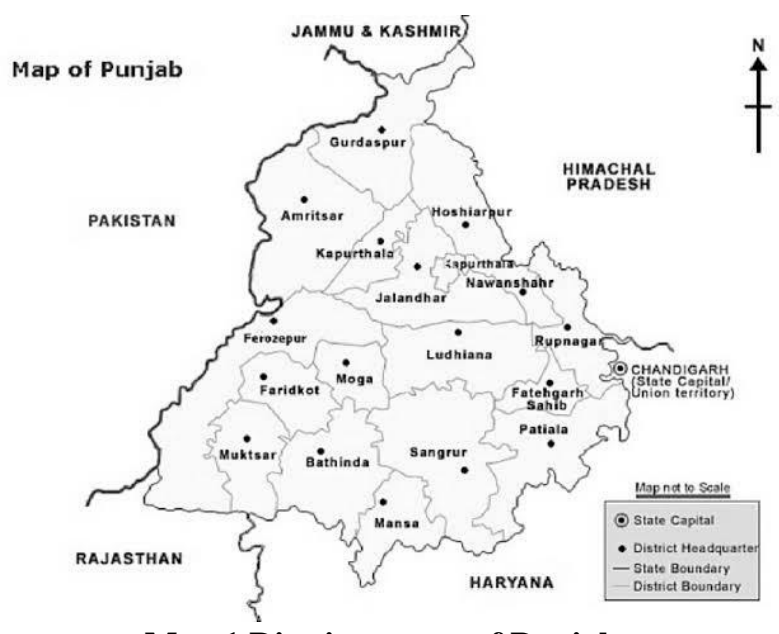

Map 1.Districts zones of Punjab

The present study was conducted in Eucalyptus hybrid,species plantations of different ages at different sites in 10 Forest Divisions of Punjab namely Amritsar, Ludhiana, Hoshiarpur, Patiala, Muktsar, Jalandhar, Bhatinda, Ferozepur, Faridkot, Roopnagar/Ropar representing three agro-climatic zones of Punjab (Sehgalet al.1990) as clearly described above and shown in the Map 1.The study sites of present study and species studied in all three agro-climatic zones of Punjab are depicted in the table below:-

Table 1.Agro-Climatic Zones of Experimental Study sites

\begin{tabular}{|c|c|c|c|}
\hline $\begin{array}{l}\text { Agro- } \\
\text { climati } \\
\text { c } \\
\text { regions }\end{array}$ & Climate & $\begin{array}{l}\text { Districts } \\
\text { covered }\end{array}$ & Dominant Species \\
\hline $\begin{array}{l}\text { Hot } \\
\text { arid } \\
(2)\end{array}$ & $\begin{array}{l}\text { Western } \\
\text { plains } \\
\text { and } \\
\text { Kutch } \\
\text { peninsul } \\
\text { a }\end{array}$ & $\begin{array}{l}\text { Ferozpur, } \\
\text { Faridkot, } \\
\text { Muktsar, } \\
\text { Bhatinda }\end{array}$ & $\begin{array}{c}\text { Eucalyptus } \\
\text { hybridandDalbergiasis } \\
\text { soo }\end{array}$ \\
\hline $\begin{array}{l}\text { Hot } \\
\text { semi- } \\
\text { arid } \\
(4)\end{array}$ & $\begin{array}{l}\text { Northern } \\
\text { plains } \\
\text { and } \\
\text { central } \\
\text { highland } \\
\text { s }\end{array}$ & $\begin{array}{l}\text { Amritsar, } \\
\text { Jalandhar, } \\
\text { Ludhiana, } \\
\text { Patiala }\end{array}$ & $\begin{array}{c}\text { Eucalyptus hybrid } \\
\text { andDalbergiasissoo }\end{array}$ \\
\hline $\begin{array}{l}\text { Hot } \\
\text { sub- } \\
\text { humid } \\
(9)\end{array}$ & $\begin{array}{l}\text { Northern } \\
\text { plain }\end{array}$ & $\begin{array}{l}\text { Hoshiarpu } \\
\text { r, } \\
\text { Roopnagar } \\
\text { (Ropar) }\end{array}$ & $\begin{array}{c}\text { Eucalyptus hybrid, } \\
\text { Dalbergiasissoo, } \\
\text { Acacia catechu and } \\
\text { Populus species }\end{array}$ \\
\hline
\end{tabular}

\section{MATERIALS \& METHODS}

3.1 Diameter and height correlation and selection of sample trees for harvesting

There is always a high correlation between DBH (Diameter at Breast Height $1.37 \mathrm{~m}$ ), height and weight of a particular tree, that's why measurement of diameter and height has been universally recognised to be a reliable measure of growth of trees. Thus it becomes essential to measure all the $\mathrm{DBH}$ and height of some of the trees in a sample plot. Regression of height and diameter can be used to estimate the height of the remaining trees, a free hand curve may also serve the purpose.

In the present study the field data was collected using stratified tree technique method of Art and Marks (1971) for harvesting the sample trees, for which sample plots of different sizes $(10 \times 10 \mathrm{~m}, 15 \times 15 \mathrm{~m}, 20 \times 20 \mathrm{~m}, 25 \times 25 \mathrm{~m}, 30$ $x 30 \mathrm{~m}$ and $50 \times 50 \mathrm{~m}$ ) were laid out according to the size of the area in all the plantations of Eucalyptus hybrid. The DBH of all the standing trees in the sample plots and heights of only 15 representative sample trees covering the entire diameter range of each plot were recorded and correlation (diameter \& height) was established by having regression coefficient $\left(\mathrm{R}^{2}\right)$ values. The entire diameter range was then divided into different diameter classes. Three sample trees from each diameter class (close to the mean DBH of that class) were harvested in each plantation for their biomass estimation.

\subsection{Biomass, productivity calculations}

All the tree components (leaves, twigs, branches, bark, bole) including roots were separated immediately after felling and their fresh weights were recorded in the felled fields. The representative samples of each tree component (100 g each sample of leaves, twigs, branches, bark, fruit) were taken for oven dry weight estimation and chemical analysis for different macronutrients in the Laboratory conditions.

The bole portion of the sample trees was cut into $2 \mathrm{~m}$ each long sections (billets) for convenience of weighing. Approximately $5 \mathrm{~cm}$ broad thick disc was removed from the base of each billet for estimation of fresh and dry weights of bark and wood (under bark) and also for the estimation of volume (over bark and under bark) of the main bole (upto a diameter limit of $5 \mathrm{~cm}$ over bark). The average diameter of the two successive discs was taken to calculate the volume (over bark and under bark) of each section and finally the volume of each section was added up to get the volume of main bole (over bark and under bark).

The root systems of all the sample trees were completely excavated excluding their fine rootlets. All possible care was taken to remove the soil particles sticking to the roots and fresh weight taken immediately to prevent the weight loss. Representative root sample was also taken for its dry weight estimation and determining mineral contents.

The stand biomass $\left(\mathrm{t} \mathrm{ha}^{-1}\right)$ was obtained by multiplying the dry weights of the sample trees by the number of tree in respective diameter classes followed by summation of biomass in each diameter class.

For calculating productivity the total biomass values are divided by number of trees per hectare of each study site. Thus productivity per tree per year or productivity per hectare per year is obtained for all the species under study.

A total of 17 trees of Eucalyptus hybrid, were felled from the experimental sites where permission of felling was given by the Punjab Forest Department. Felling in other sites could not be done without permission of felling, although it was required/ requested for better results. 


\subsection{Developing Regression EquationsforTree Biomass Estimation}

In order to predict biomass and productivity of any forest stand on a regional basis a set of regressions are derived between easily measurable parameters (DBH \& Height) and dry weight of different tree components (leaves, twigs, branches, bole, bark, root). These prediction equations would obviate a great extent the necessity of destructive sampling, which is not always convenient and possible for various reasons.

The basic data obtained from sample trees felled were used to get different regression equations. These sample trees covered fairly wide range of variations in the growth of the species and site factors. The actual figures of dry weight of various tree components of all the trees felled for all Eucalyptus tree species were plotted against $\mathrm{D}^{2} \mathrm{H}$ values of each tree and the equations or model were tried as

$\log y=a+\log b x$

Where ' $y$ ' is a biomass component expressed in $\mathrm{kg}$ and ' $\mathrm{x}$ ' is the $\mathrm{D}^{2} \mathrm{H}$ i.e. diameter $\&$ height values, ' $\mathrm{a}$ ' \& ' $\mathrm{b}$ ' are the regression constants, respectively. The value of ' $\mathrm{x}$ ' was also tried with $\mathrm{DBH}$ (diameter) and $\mathrm{D}^{2}$ also but $\mathrm{D}^{2} \mathrm{H}$ (diameter and height together) was found to be best suited for all the species.For validation, regression equations were also worked out on the basis of 17 trees felled for $E$. hybrid and predicted biomass (using these equations) values of average 6 trees (from each site with varying diameter $\&$ height) were compared with actual biomass of these average 6 trees (felled).

\section{RESULTS AND DISCUSSIONS}

\subsection{Eucalyptus hybrid Biomass and Productivity}

For biomass estimation of Eucalyptus diameter and height correlations were established at Nara, Kharkan, Dholbah, Katour (Hoshiarpur Forest Division), Doraha and Ludhiana Reserve Forest (Ludhiana Forest Div.), Kamalpur (Amritsar Forest Div.), Phillaur and Talwandi-Bhai (Jalandhar Forest Div.), Mukt-Doda-Sota Road, Faridkot and Nabha-BirMehas (Muktsar Forest Div.), Thapar Engineering College (TEC) (Patiala Forest Div.).

Diameter and height correlation in all these study sites have been shown in the Figures (I - XIV). The best correlation of diameter and height $\left(r^{2}=0.85\right)$ was observed in DholbahDehra (Hoshiarpur Forest Division) i.e. with increase in diameter height has also increasing trend, whereas the lowest value $\left(r^{2}=0.20\right)$ was observed in Muktsar-Doda-SotaRoad (Muktsar Forest Division) which means with increasing diameter height does not show increasing trend.

\subsubsection{Biomass}

Sample trees at different Forest Divisions along with their mean diameter, height, biomass $(\mathrm{kg})$ of each component of each tree, above ground biomass (AGB), root biomass (below ground biomass or $\mathrm{BGB}$ ) and the total biomass $(\mathrm{AGB}+\mathrm{BGB})(\mathrm{kg} / \mathrm{tree})$ of all the sample trees have been depicted in the Table 1 .

As it is evident from the Table 2. that these plantations show a range of variation in their age $(18-30$ years $)$, density $(232$ - 740 trees $\left.\mathrm{ha}^{-1}\right)$, diameter $(12.7 \mathrm{~cm}$ to $49.75 \mathrm{~cm})$, height (14.4 to $41.5 \mathrm{~m})$ and total biomass $\left(112.98 \mathrm{t} \mathrm{ha}^{-1}\right.$ to $531.09 \mathrm{t}$ $\mathrm{ha}^{-1}$ ). The variation in biomass depends on combination of factors including size of tree, density (spacing)/ no. of trees per plot and variation of locality factors. The results show direct relationship of biomass with diameter and height of the tree. More the diameter and height more is the biomass in most of the cases, although number of trees per hectare also plays significant role in assessing the total biomass of an area as can be seen in Table 2 .

\subsubsection{Productivity}

Productivity of a vegetation stand depends on the total biomass and age of the stand; biomass in turn is dependent on diameter /height and number of trees present in a stand. Hence, with variation in all these parameters the values of productivity also changes as is clear from the Table 2 . The productivity has ranged from $3.77 \mathrm{t} \mathrm{ha}^{-1} \mathrm{yr}^{-1}$ at Kamalpur I to $18.65 \mathrm{t} \mathrm{ha}^{-1} \mathrm{yr}^{-1}$ at Faridkot. This value of Faridkot is estimated as per regression equation developed on the basis of 17 trees felled at various sites of Punjab, as has been already mentioned that no permission of felling was permitted from this agro-climatic zone. Hence for the sake of comparison of productivity of Hot arid zone with other zones of the state, estimated values are used. The peak productivity calculated was recorded to be the highest at Patiala as $8.03 \mathrm{t} \mathrm{ha}^{-1} \mathrm{yr}^{-1}$ on single tree basis as well as on average of three trees basis $\left(17.7 \mathrm{t} \mathrm{ha}^{-1} \mathrm{yr}^{-1}\right)$ and the lowest at Katour (5.89 $\left.\mathrm{t} \mathrm{ha}^{-1} \mathrm{yr}^{-1}\right)$.

The productivity of all these three agro-climatic zones were also compared and found that the highest productivity was recorded from Hot arid zone (18.65 $\mathrm{t} \mathrm{ha}^{-1} \mathrm{yr}^{-1}$ ), then in Hot semi-arid zone (16.94 $\left.\mathrm{tha}^{-1} \mathrm{yr}^{-1}\right)$ and minimum productivity was in the Hot sub-humid zone $\left(8.03 \mathrm{t} \mathrm{ha}^{-1} \mathrm{yr}^{-1}\right)$. Thus the sequence of peak productivity in three agro-climatic zones is as; Hot arid zone > Hot semi-arid zone >Hot sub-humid zone.

$E$. hybrid plantations in Hot arid zone of Punjab are in strips along roadside or drains, which are adjacent to agriculture fields. As farmers of Punjab have been using fertilizers in good quantities these plantations must have got affected by use of these fertilizers. Besides this, in narrow strip plantations the outer rows gain higher diameter which can ultimately result in higher biomass. This may be the reason Faridkot has higher biomass / productivity. Luna et al. (2006) have also reported that Eucalyptus can grow better under agroforestry plantations in Hot arid zone (2) than Hot semi-arid zone (4) and Hot sub-humid zone (9) of Punjab State, which they have reported on the basis of site quality of these zones.

Biomass contributions of different tree components to total biomass are also worked out and presented in Table 3. The variation in other biomass components are: leaf biomass $\left(1.08 \mathrm{~kg}\right.$ tree ${ }^{-1}$ to $29.95 \mathrm{~kg}$ tree $\left.^{-1}\right)$, twig biomass (1.62 to $31.92 \mathrm{~kg} \mathrm{tree^{-1 }}$ ), branch biomass (6.36 to $\left.151.56 \mathrm{~kg}^{-1} \mathrm{tre}^{-1}\right)$, bark (8.32 to $168.77 \mathrm{~kg}$ tree ${ }^{-1}$ ), bole biomass (55.88 to $1911.41 \mathrm{~kg}$ tree $\left.^{-1}\right)$, root biomass / Below Ground Biomass (BGB) (9.36 to $397.20 \mathrm{~kg}^{-1} \mathrm{ee}^{-1}$ ) and total biomass (72.41 to $2255.30 \mathrm{~kg}$ tree $\left.^{-1}\right)$. Most of the upper range of all the biomass components are at Patiala at the age of 30 years whereas the lower range has been varying component wise.

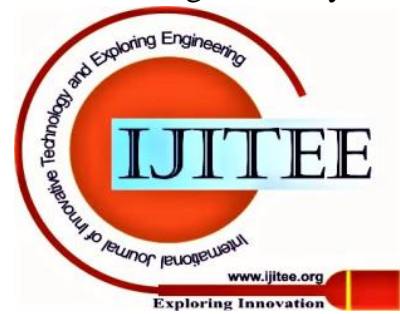


Table 3.also shows the average percentage contribution of the biomass of each component to total biomass (above ground \& below ground) in all study sites. The contribution of individual tree components to total biomass varied as: leaf 1.40 to $2.63 \%$; twig 1.30 to $2.69 \%$, branch 5.40 to $7.71 \%$, bark 5.23 to $8.61 \%$, root 12.51 to $14.48 \%$ and bole 66 to $74.18 \%$ and root from $12.51-14.48 \%$ to total biomass. There is no correlation between age and the biomass of different components as reported by Singh and Sharma (1976), George (1977), Negi (1984) etc, which may be because the present study was undertaken in mature monoculture plantations (ages 18 - 30 years), whereas the earlier studies were conducted in trees of 5-17 years of age.

Figure-I: Nara

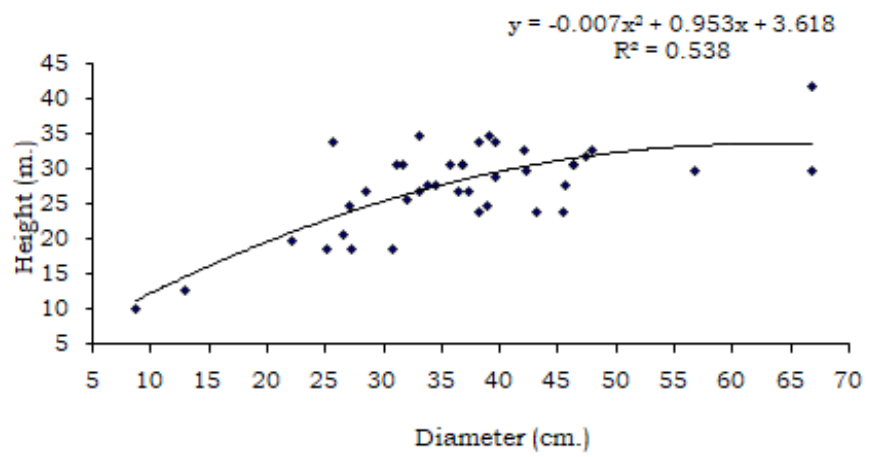

Figure-III: Dholwaha
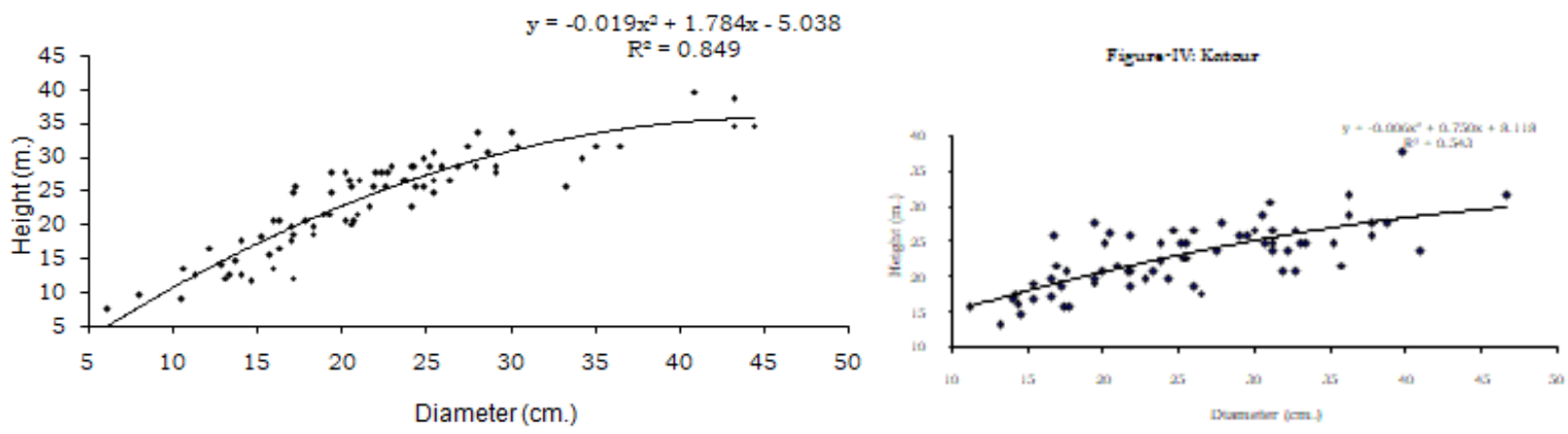

Figure-VI: Ludhiana RF
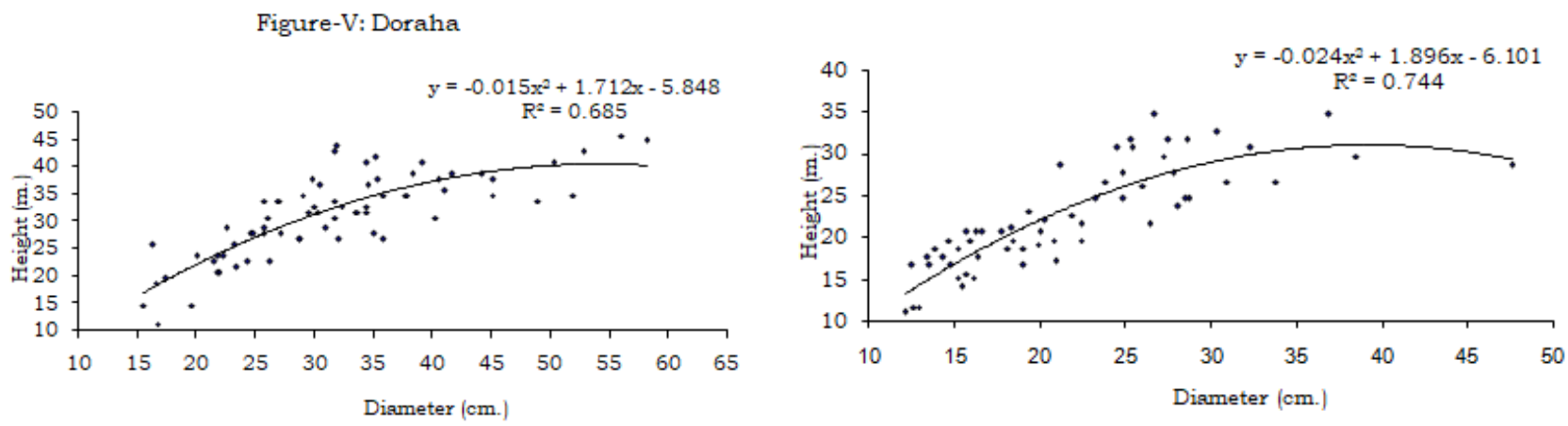

The percentage $(\%)$ contribution of different tree components at different sites were as: Patiala leaf 1.4, twig 1.48 , branch 6.1 , bark 6.13 , bole 71.57 and root $13.31 \%$ respectively. At Ludhiana leaf, twig, branch, bark, bole and root percentages were 1.18, 1.3, 5.4, 5.21, 74.18 and 12.51 $\%$, respectively. At Hoshiarpur the percentages were in the range of $2.08-2.63,1.52-2.69,5.77-7.71,7.25-8.24$, $66.06-68.88$ and $13.02-14.48$ percent at different sites, respectively, in the above components in the same sequence. The percent contributions of all these components in all the sites were as bole $>$ root $>$ bark $>$ branch $>$ twig $>$ leaf.(Table 3 .)

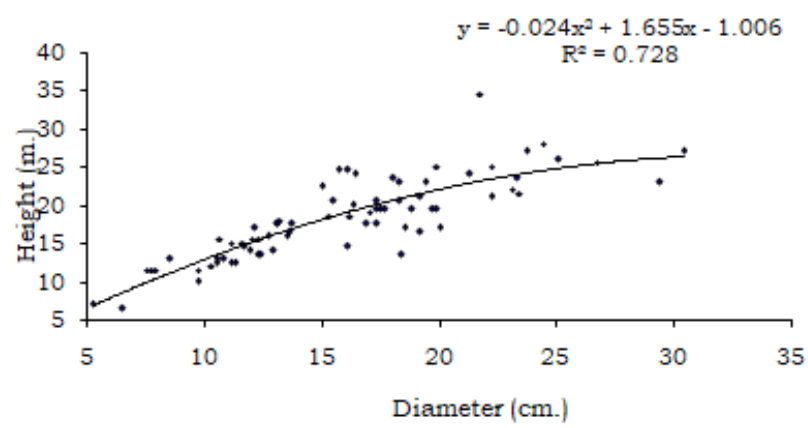

Figure-II: Kharkan 
Development of Prediction Regression Equations for Biomass Estimation in Eucalyptus Forest Plantations in the Punjab State of India

Figure-VII: Ajnala

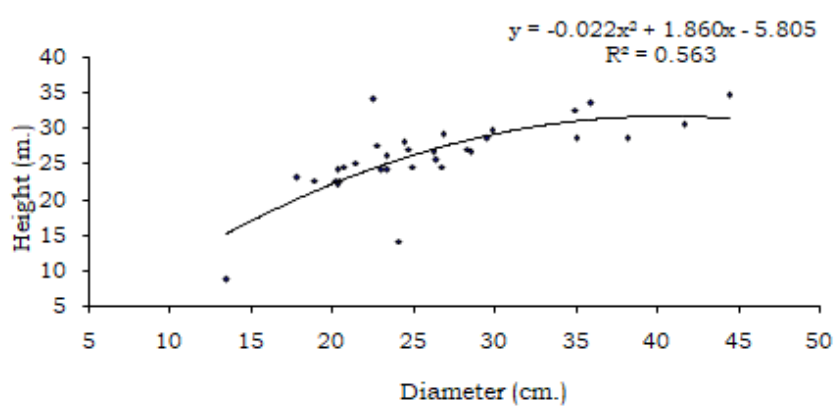

Figure-VIII: Phillaur

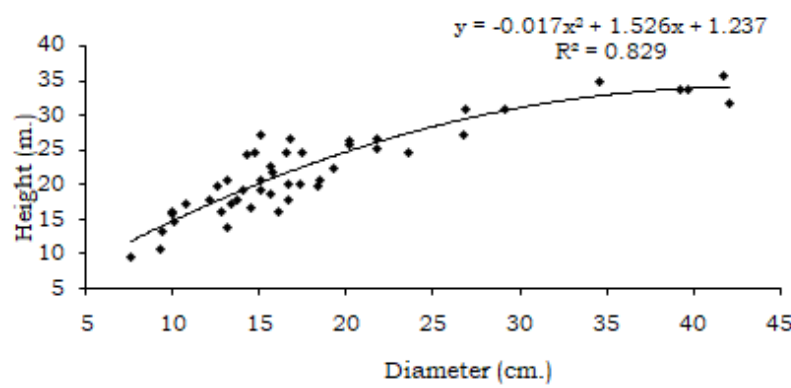

Fig 1. Diameter height correlations in Eucalyptus plantations

Figure-IX: Talwandi-Bhai

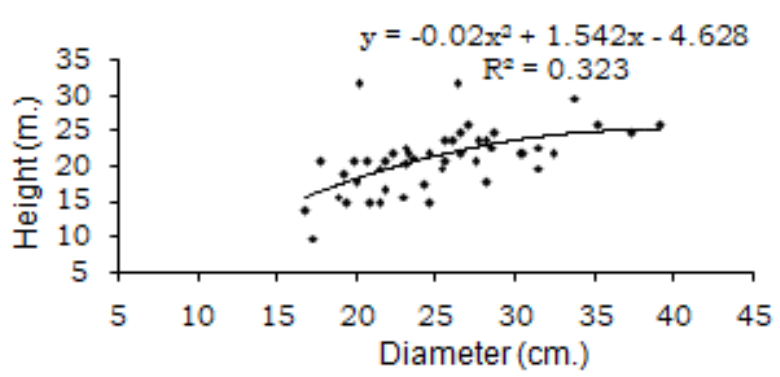

Figure-XI: Faridkot I (Feeder canal RD No. 122-123)

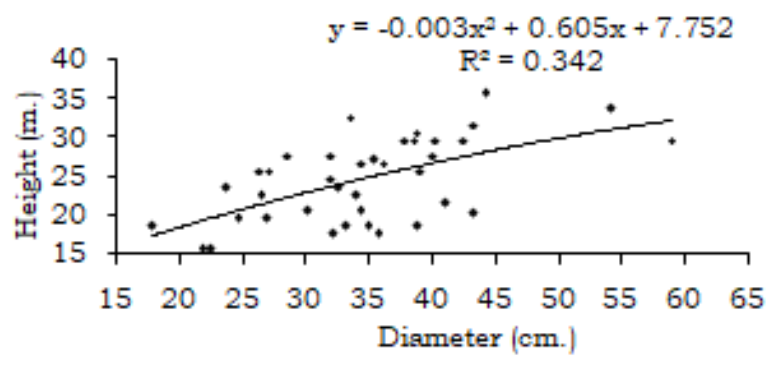

Figure-XIII: Nabha, Bir-Mehas

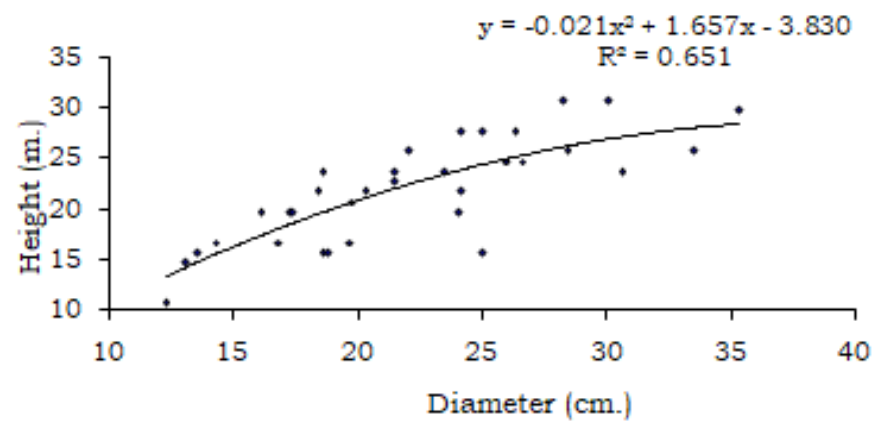

Figure-X: Muktsar (Doda Sota Road)

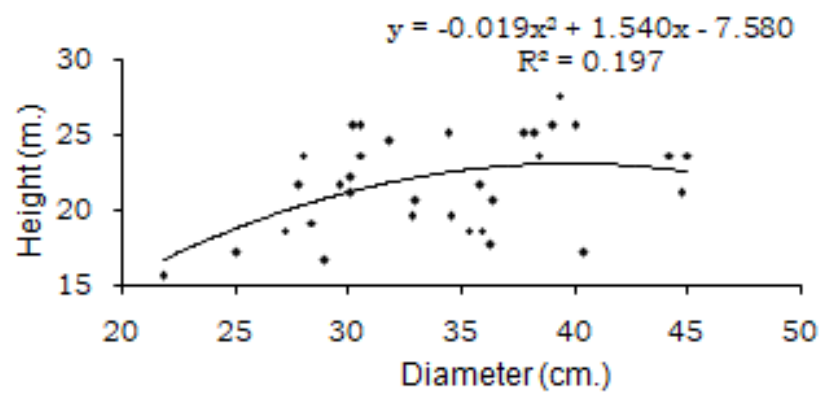

Figure-XII: Faridkot - II (Feeder canal RD No. 109-110) $y=-0.007 x^{2}+1.010 x-11.25$

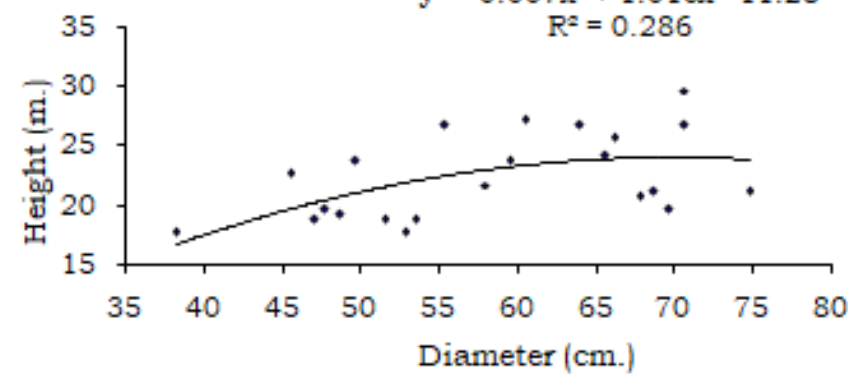

Figure-XIV: Patiala (Thappar Engeneering College)

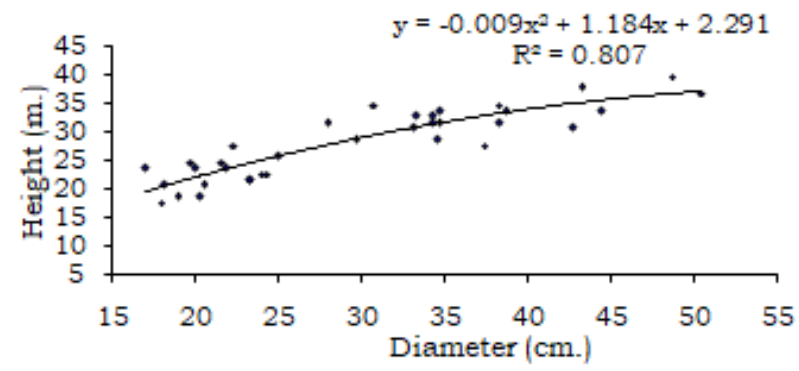

Fig 1.Contd. 
International Journal of Innovative Technology and Exploring Engineering (IJITEE) ISSN: 2278-3075, Volume-8 Issue-10S2, August 2019

Table 1.Calculated Biomass $\left(\mathrm{kg} \mathrm{tree}^{-1}\right)$ of Eucalyptus hybrid at different sites of Punjab.

\begin{tabular}{|c|c|c|c|c|c|c|c|c|c|c|c|c|c|}
\hline $\begin{array}{c}\text { Forest Div. } \\
\text { (Agro } \\
\text { climatic } \\
\text { zone) }\end{array}$ & $\begin{array}{c}\text { Locality / } \\
\text { Site }\end{array}$ & $\begin{array}{l}\text { Age } \\
\text { (Yrs } \\
\text { ) }\end{array}$ & $\begin{array}{l}\text { Mean dia. } \\
\quad(\mathrm{cm})\end{array}$ & $\begin{array}{c}\text { Heigh } \\
\mathrm{t} \\
(\mathrm{m})\end{array}$ & Leaf & Twig & $\begin{array}{c}\text { Branc } \\
h\end{array}$ & Bark & Bole & $\begin{array}{c}\text { Frui } \\
\mathrm{t}\end{array}$ & AGB & Root & $\begin{array}{c}\text { Total } \\
\text { Biomass }\end{array}$ \\
\hline $\begin{array}{l}\text { 1.Patiala } \\
\text { (4) }\end{array}$ & TEC Patiala & & & & \multicolumn{6}{|c|}{$(\mathrm{kg})$} & \multicolumn{3}{|c|}{$\left(\mathrm{kg}\right.$ tree $\left.^{-1}\right)$} \\
\hline & 1 & 30 & 19 & 24.3 & 7.96 & $\begin{array}{c}10.7 \\
3\end{array}$ & 34.1 & 31.24 & 269.1 & & 353.13 & 31.92 & 385.05 \\
\hline & 2 & 30 & 30 & 35.55 & $\begin{array}{c}20.8 \\
8\end{array}$ & $\begin{array}{c}23.6 \\
6\end{array}$ & 105.25 & 59.51 & 857.23 & & $\begin{array}{c}1066.5 \\
3\end{array}$ & $\begin{array}{c}131.5 \\
2\end{array}$ & 1198.05 \\
\hline & 3 & 30 & 49.75 & 36.2 & $\begin{array}{c}29.9 \\
5\end{array}$ & $\begin{array}{c}27.7 \\
2\end{array}$ & 117.45 & $\begin{array}{c}162.7 \\
7\end{array}$ & $\begin{array}{c}1911.4 \\
1\end{array}$ & & 2249.3 & 397.2 & 2646.5 \\
\hline \multirow[t]{5}{*}{$\begin{array}{c}\text { 2.Ludhiana } \\
\text { (4) }\end{array}$} & Doraha & & & & & & & & & & & & \\
\hline & 4 & 28 & 17.8 & 16.4 & 2.41 & 4.14 & 15.98 & 9.96 & 84.22 & & 116.71 & 20 & 136.71 \\
\hline & 5 & 28 & 23.1 & 25.1 & 3.32 & 6.27 & 14.95 & 24.4 & 241.33 & & 290.27 & 51.12 & 341.39 \\
\hline & 6 & 28 & 28.8 & 37.1 & 8 & 6.82 & 26.4 & 30.59 & 507.11 & 1.05 & 579.97 & 68.25 & 648.22 \\
\hline & 7 & 28 & 38.5 & 41.15 & $\begin{array}{c}16.4 \\
3\end{array}$ & 16 & 81.12 & 69.72 & 1080.1 & 4.56 & $\begin{array}{c}1267.9 \\
3\end{array}$ & 181.2 & 1449.13 \\
\hline \multirow[t]{13}{*}{$\begin{array}{c}\text { 3.Hoshiarpu } \\
\mathrm{r} \\
(9) \\
\end{array}$} & Dholbaha & & & & & & & & & & & & \\
\hline & 8 & 18 & 13.6 & 16.7 & 1.44 & 1.62 & 7.99 & 10.53 & 57.47 & 0.44 & 79.49 & 11.55 & 91.04 \\
\hline & 9 & 18 & 17.8 & 22.4 & 9.88 & 8.5 & 19.76 & 16.77 & 142.05 & 0.43 & 197.39 & 42.34 & 239.73 \\
\hline & 10 & 18 & 26.7 & 24.1 & $\begin{array}{c}14.6 \\
2\end{array}$ & $\begin{array}{c}14.2 \\
1\end{array}$ & 51.84 & 50.17 & 328.56 & 7.22 & 466.62 & $\begin{array}{c}102.8 \\
5\end{array}$ & 569.47 \\
\hline & Katour & & & & & & & & & & & & \\
\hline & 11 & 30 & 42.5 & 33.8 & 26.4 & $\begin{array}{c}18.2 \\
5\end{array}$ & 114.21 & $\begin{array}{c}110.0 \\
4\end{array}$ & $\begin{array}{c}1142.5 \\
7\end{array}$ & 1.2 & $\begin{array}{c}1412.6 \\
7\end{array}$ & $\begin{array}{c}207.4 \\
8\end{array}$ & 1620.15 \\
\hline & 12 & 30 & 17.6 & 22.7 & 3.92 & 2.75 & 13.77 & 14.49 & 155.53 & & 190.46 & 48.43 & 238.89 \\
\hline & 13 & 30 & 26.8 & 29.2 & $\begin{array}{c}13.7 \\
8\end{array}$ & $\begin{array}{c}11.0 \\
2\end{array}$ & 34 & 56.05 & 497.95 & & 612.8 & 89.09 & 701.89 \\
\hline & Kharkan & & & & & & & & & & & & \\
\hline & 14 & 30 & 27.7 & 26.2 & 16.5 & $\begin{array}{c}10.2 \\
9\end{array}$ & 43.31 & 46.7 & 433.47 & & 550.27 & 83.79 & 634.06 \\
\hline & 15 & 30 & 12.7 & 17.9 & 4.37 & 2.08 & 6.36 & 8.29 & 55.88 & & 76.98 & 13.23 & 90.21 \\
\hline & 16 & 30 & 17.7 & 22.5 & 6.9 & 6.48 & 16.64 & 17.01 & 139.05 & & 186.08 & 27.03 & 213.11 \\
\hline & 17 & 30 & 21.5 & 23.9 & 7.5 & 8.5 & 28.6 & 31 & 261.89 & 0.78 & 338.27 & 49.8 & 388.07 \\
\hline \multirow[t]{8}{*}{$\begin{array}{c}\text { 3.Amritsar } \\
\text { (4) }\end{array}$} & Kamalpur-I & & & & & & & & & & & & \\
\hline & 18 & 30 & 13.5 & 14.4 & 1.08 & 3.58 & 15.56 & 9.44 & 42.75 & & 72.41 & 16.7 & 89.11 \\
\hline & 19 & 30 & 22.5 & 24.25 & 3.38 & 7.14 & 36.68 & 29.02 & 251.27 & & 327.49 & 74.53 & 402.02 \\
\hline & 20 & 30 & 35 & 27.5 & $\begin{array}{c}20.1 \\
6\end{array}$ & $\begin{array}{c}20.2 \\
8\end{array}$ & 97.47 & 55.44 & 604.78 & & 798.13 & 118.8 & 916.93 \\
\hline & Kamalpur-II & & & & & & & & & & & & \\
\hline & 21 & 30 & 31.8 & 28.2 & 12 & 11.1 & 117 & 51.31 & 582.31 & & 773.72 & $\begin{array}{c}103.0 \\
4\end{array}$ & 876.76 \\
\hline & 22 & 30 & 39 & 29 & $\begin{array}{c}22.7 \\
9\end{array}$ & \begin{tabular}{|c|}
17.2 \\
5 \\
\end{tabular} & 144.1 & 78.05 & 692.09 & & 954.28 & 9.36 & 963.64 \\
\hline & 23 & 30 & 40.1 & 28.9 & $\begin{array}{c}17.1 \\
6\end{array}$ & $\begin{array}{c}31.9 \\
2\end{array}$ & 154.56 & 95.06 & 983 & & 1281.7 & $\begin{array}{c}265.6 \\
5\end{array}$ & 1547.35 \\
\hline
\end{tabular}


Development of Prediction Regression Equations for Biomass Estimation in Eucalyptus Forest Plantations in the Punjab State of India

Table 2.. Calculated Biomass $\left(\mathrm{t} \mathrm{ha}^{-1}\right)$ and productivity $\left(\mathrm{t} \mathrm{ha}^{-1} \mathrm{yr}^{-1}\right)$ of Eucalyptus hybrid at different sites of Punjab

\begin{tabular}{|c|c|c|c|c|c|c|c|c|c|c|}
\hline $\begin{array}{l}\text { Forest Div. } \\
\text { (Agro climatic } \\
\text { zone) }\end{array}$ & $\begin{array}{l}\text { Locality / } \\
\text { Site }\end{array}$ & Trees & $\begin{array}{l}\text { Age } \\
\text { (Yrs) }\end{array}$ & $\begin{array}{c}\text { Mean dia. } \\
(\mathrm{cm})\end{array}$ & $\begin{array}{l}\text { Height } \\
\text { (m) }\end{array}$ & $\begin{array}{l}\text { Biomass } \\
\left(\mathrm{kg} \mathrm{tree}^{-1}\right)\end{array}$ & $\begin{array}{c}\text { Biomass } \\
\left(\begin{array}{c}\mathrm{t} \text { tree } \\
1\end{array}\right.\end{array}$ & $\begin{array}{l}\text { No. of } \\
\text { trees } \text { ha }^{-1}\end{array}$ & $\begin{array}{c}\text { Biomass } \\
\left(\mathrm{t} \mathrm{ha}^{-1}\right)\end{array}$ & $\begin{array}{l}\text { Productivity } \\
\left(\mathrm{t} \mathrm{ha}^{-1} \mathrm{yr}^{-1}\right)\end{array}$ \\
\hline \multirow{4}{*}{$\begin{array}{l}\text { 1.Patiala } \\
\text { (4) }\end{array}$} & \multirow[t]{4}{*}{ T.E.C.Patiala } & 1 & 30 & 19.00 & 24.30 & 385.04 & 0.39 & 256.00 & 98.57 & 3.29 \\
\hline & & 2 & 30 & 30.00 & 35.55 & 1198.05 & 1.20 & 160.00 & 191.69 & 6.39 \\
\hline & & 3 & 30 & 49.75 & 36.10 & 2646.50 & 2.65 & 91.00 & 240.83 & 8.03 \\
\hline & & & & & Total & 4229.59 & 4.23 & 507.00 & 531.09 & 17.71 \\
\hline \multirow{5}{*}{$\begin{array}{l}\text { 2.Ludhiana } \\
\text { (4) }\end{array}$} & \multirow[t]{5}{*}{ Doraha } & 4 & 28 & 17.80 & 16.40 & 136.71 & 0.14 & 175.00 & 23.92 & 0.85 \\
\hline & & 5 & 28 & 23.10 & 25.10 & 341.18 & 0.34 & 49.00 & 16.72 & 0.60 \\
\hline & & 6 & 28 & 28.80 & 37.10 & 648.21 & 0.65 & 133.00 & 86.21 & 3.08 \\
\hline & & 7 & 28 & 38.50 & 41.15 & 1449.13 & 1.45 & 203.00 & 294.17 & 10.51 \\
\hline & & & & & Total & 2575.23 & 2.57 & 560.00 & 421.02 & 15.04 \\
\hline \multirow{13}{*}{$\begin{array}{l}\text { 3.Hoshiarpur } \\
\text { (9) }\end{array}$} & \multirow[t]{4}{*}{ Dholbaha } & 8 & 18 & 13.60 & 16.70 & 91.04 & 0.09 & 130.00 & 11.84 & 0.66 \\
\hline & & 9 & 18 & 17.80 & 22.40 & 239.73 & 0.24 & 232.00 & 55.62 & 3.09 \\
\hline & & 10 & 18 & 26.70 & 24.10 & 564.47 & 0.56 & 247.00 & 139.42 & 7.75 \\
\hline & & & & & Total & 895.24 & 0.89 & 609.00 & 206.88 & 11.50 \\
\hline & \multirow[t]{4}{*}{ Katour } & 11 & 30 & 42.50 & 33.80 & 1620.15 & 1.62 & 48.00 & 77.77 & 2.59 \\
\hline & & 12 & 30 & 17.60 & 22.70 & 238.89 & 0.19 & 105.00 & 25.08 & 0.84 \\
\hline & & 13 & 30 & 26.80 & 29.20 & 701.89 & 0.61 & 129.00 & 90.54 & 3.02 \\
\hline & & & & & Total & 2560.93 & 2.42 & 282.00 & 193.39 & 6.45 \\
\hline & \multirow[t]{5}{*}{ Kharkan } & 14 & 30 & 27.70 & 26.20 & 634.06 & 0.63 & 234.00 & 148.37 & 4.95 \\
\hline & & 15 & 30 & 12.70 & 17.90 & 90.21 & 0.09 & 52.00 & 4.69 & 0.16 \\
\hline & & 16 & 30 & 17.70 & 22.50 & 212.51 & 0.21 & 61.00 & 12.96 & 0.43 \\
\hline & & 17 & 30 & 21.50 & 23.90 & 388.07 & 0.39 & 90.00 & 34.93 & 1.16 \\
\hline & & & & & Total & 1324.85 & 1.32 & 437.00 & 200.95 & 6.70 \\
\hline \multirow{8}{*}{$\begin{array}{l}\text { 4.Amritsar } \\
\text { (4) }\end{array}$} & \multirow[t]{4}{*}{ Kamalpur - I } & 18 & 30 & 13.50 & 14.40 & 89.11 & 0.09 & 16.00 & 1.43 & 0.05 \\
\hline & & 19 & 30 & 22.50 & 24.25 & 402.02 & 0.40 & 168.00 & 67.54 & 2.25 \\
\hline & & 20 & 30 & 35.00 & 27.50 & 916.93 & 0.92 & 48.00 & 44.01 & 1.47 \\
\hline & & & & & Total & 1408.06 & 1.41 & 232.00 & 112.98 & 3.77 \\
\hline & \multirow{4}{*}{$\begin{array}{c}\text { Kamalpur - } \\
\text { II }\end{array}$} & 21 & 30 & 31.80 & 28.20 & 876.76 & 0.88 & 60.00 & 52.61 & 1.75 \\
\hline & & 22 & 30 & 39.00 & 29.00 & 963.64 & 0.96 & 79.00 & 76.13 & 2.54 \\
\hline & & 23 & 30 & 40.10 & 28.90 & 1547.35 & 1.55 & 48.00 & 74.27 & 2.48 \\
\hline & & & & & Total & 3387.75 & 3.39 & 187.00 & 203.01 & 6.77 \\
\hline \multirow{4}{*}{$\begin{array}{l}\text { 5.Faridkot* } \\
\text { (2) }\end{array}$} & \multirow[t]{4}{*}{ Faridkot } & 24 & 18 & 18.50 & 21.50 & 291.07 & 0.29 & 254.00 & 73.93 & 4.11 \\
\hline & & 25 & 18 & 22.60 & 24.40 & 381.94 & 0.38 & 238.00 & 90.90 & 4.05 \\
\hline & & 26 & 18 & 27.30 & 29.70 & 656.14 & 0.66 & 248.00 & 162.72 & 9.04 \\
\hline & & & & & Total & 1329.15 & 1.33 & 740.00 & 327.55 & 17.20 \\
\hline
\end{tabular}

* On the basis of prediction equation developed (Table 7.)

Table 3.Contribution of different plant components to total tree biomass of Eucalyptus trees.

\begin{tabular}{|c|c|c|c|c|c|c|c|c|c|}
\hline $\begin{array}{c}\text { Forest Div. } \\
\text { (agro - climatic } \\
\text { zone) }\end{array}$ & $\begin{array}{l}\text { Locality / } \\
\text { Site }\end{array}$ & Leaf & Twig & Branch & Bark & Bole & Fruit & $\begin{array}{c}\text { Root } \\
\text { (BGB) }\end{array}$ & $\begin{array}{c}\text { Total } \\
\text { Biomass }\end{array}$ \\
\hline $\begin{array}{c}\text { 1.Patiala } \\
(4)\end{array}$ & $\begin{array}{c}\text { TEC } \\
\text { Patiala } \\
\end{array}$ & \multicolumn{6}{|c|}{$(\mathrm{Kg})$} & \multicolumn{2}{|c|}{$\left(\mathrm{kg}\right.$ tree $\left.^{-1}\right)$} \\
\hline & & 7.96 & 10.73 & 34.10 & 31.24 & 269.10 & & 31.92 & 385.05 \\
\hline & & 20.88 & 23.66 & 105.25 & 59.51 & 857.23 & & 131.52 & 1198.05 \\
\hline & & 29.95 & 27.72 & 117.45 & 162.77 & 1911.41 & & 397.20 & 2646.50 \\
\hline & Av. & 19.60 & 20.70 & 85.60 & 84.51 & 1012.58 & & 186.88 & 1409.87 \\
\hline & \begin{tabular}{|c|}
$\%$ \\
Contributio \\
$\mathrm{n}$
\end{tabular} & 1.39 & 1.47 & 6.07 & 5.99 & 71.82 & 0.00 & 13.26 & \\
\hline
\end{tabular}


International Journal of Innovative Technology and Exploring Engineering (IJITEE) ISSN: 2278-3075, Volume-8 Issue-10S2, August 2019

\begin{tabular}{|c|c|c|c|c|c|c|c|c|c|}
\hline \multirow{7}{*}{$\begin{array}{c}\text { 2.Ludhiana } \\
\text { (4) }\end{array}$} & \multicolumn{9}{|c|}{ Doraha } \\
\hline & & 2.41 & 4.14 & 15.98 & 9.96 & 84.22 & & 20.00 & 136.71 \\
\hline & & 3.32 & 6.27 & 14.95 & 24.40 & 241.33 & & 51.12 & 341.39 \\
\hline & & 8.00 & 6.82 & 26.40 & 30.59 & 507.11 & 1.05 & 68.25 & 648.22 \\
\hline & & 16.43 & 16.00 & 81.12 & 69.72 & 1080.10 & 4.56 & 181.20 & 1449.13 \\
\hline & Av. & 7.54 & 8.31 & 34.61 & 33.67 & 478.19 & 2.81 & 80.14 & 643.86 \\
\hline & \begin{tabular}{|c|}
$\%$ \\
Contributio \\
$\mathrm{n}$
\end{tabular} & 1.17 & 1.29 & 5.38 & 5.23 & 74.27 & 0.44 & 12.45 & \\
\hline $\begin{array}{c}\text { 3. Hoshiarpur } \\
(9)\end{array}$ & \multicolumn{9}{|c|}{ Dholbaha } \\
\hline & & 1.44 & 1.62 & 7.99 & 10.53 & 57.47 & 0.44 & 11.55 & 91.04 \\
\hline & & 9.88 & 8.50 & 19.76 & 16.77 & 142.05 & 0.43 & 42.34 & 239.73 \\
\hline & & 14.62 & 14.21 & 51.84 & 50.17 & 328.56 & 7.22 & 102.85 & 569.47 \\
\hline & Av. & 8.65 & 8.11 & 26.53 & 25.82 & 176.03 & 2.70 & 52.25 & 300.08 \\
\hline & \begin{tabular}{|c|}
$\%$ \\
Contributio \\
$\mathrm{n}$ \\
\end{tabular} & 2.88 & 2.70 & 8.84 & 8.61 & 58.66 & 0.90 & 17.41 & \\
\hline & \multicolumn{9}{|c|}{ Katour } \\
\hline & & 26.40 & 18.25 & 114.21 & 110.04 & 1142.57 & 1.20 & 207.48 & 1620.15 \\
\hline & & 3.92 & 2.75 & 13.77 & 14.49 & 155.53 & & 48.43 & 238.89 \\
\hline & & 13.78 & 11.02 & 34.00 & 56.05 & 497.95 & & 89.09 & 701.89 \\
\hline & Av. & 14.70 & 10.67 & 53.99 & 60.19 & 598.68 & 1.20 & 115.00 & 853.64 \\
\hline & \begin{tabular}{|c|}
$\%$ \\
Contributio \\
$\mathrm{n}$ \\
\end{tabular} & 1.72 & 1.25 & 6.33 & 7.05 & 70.13 & 0.14 & 13.47 & \\
\hline & \multicolumn{9}{|c|}{ Kharkan } \\
\hline & & 16.50 & 10.29 & 43.31 & 46.70 & 433.47 & & 83.79 & 634.06 \\
\hline & & 4.37 & 2.08 & 6.36 & 8.29 & 55.88 & & 13.23 & 90.21 \\
\hline & & 6.90 & 6.48 & 16.64 & 17.01 & 139.05 & & 27.03 & 213.11 \\
\hline & & 7.50 & 8.50 & 28.60 & 31.00 & 261.89 & 0.78 & 49.80 & 388.07 \\
\hline & Av. & 8.82 & 6.84 & 23.73 & 25.75 & 222.57 & 0.78 & 43.46 & 331.36 \\
\hline & \begin{tabular}{|c|}
$\%$ \\
Contributio \\
$\mathrm{n}$ \\
\end{tabular} & 2.66 & 2.06 & 7.16 & 7.77 & 67.17 & 0.24 & 13.12 & \\
\hline $\begin{array}{c}\text { 3.Amritsar } \\
\text { (4) }\end{array}$ & \multicolumn{9}{|c|}{ Kamalpur-I } \\
\hline & & 1.08 & 3.58 & 15.56 & 9.44 & 42.75 & & 16.70 & 89.11 \\
\hline & & 3.38 & 7.14 & 36.68 & 29.02 & 251.27 & & 74.53 & 402.02 \\
\hline & & 20.16 & 20.28 & 97.47 & 55.44 & 604.78 & & 118.80 & 916.93 \\
\hline & Av. & 8.21 & 10.33 & 49.90 & 31.30 & 299.60 & & 70.01 & 469.35 \\
\hline & \begin{tabular}{|c|}
$\%$ \\
Contributio \\
$\mathrm{n}$
\end{tabular} & 1.75 & 2.20 & 10.63 & 6.67 & 63.83 & 0.00 & 14.92 & \\
\hline & \multicolumn{9}{|c|}{ Kamalpur-II } \\
\hline & & 12.00 & 11.10 & 117.00 & 51.31 & 582.31 & & 103.04 & 876.76 \\
\hline & & 22.79 & 17.25 & 144.10 & 78.05 & 692.09 & & 9.36 & 963.64 \\
\hline & & 17.16 & 31.92 & 154.56 & 95.06 & 983.00 & & 265.65 & 1547.35 \\
\hline & Av. & 17.32 & 20.09 & 138.55 & 74.81 & 752.47 & & 126.02 & 1129.25 \\
\hline & \begin{tabular}{|c|}
$\%$ \\
Contributio \\
$\mathrm{n}$
\end{tabular} & 1.53 & 1.78 & 12.27 & 6.62 & 66.63 & 0.00 & 11.16 & \\
\hline
\end{tabular}


Development of Prediction Regression Equations for Biomass Estimation in Eucalyptus Forest Plantations in the Punjab State of India

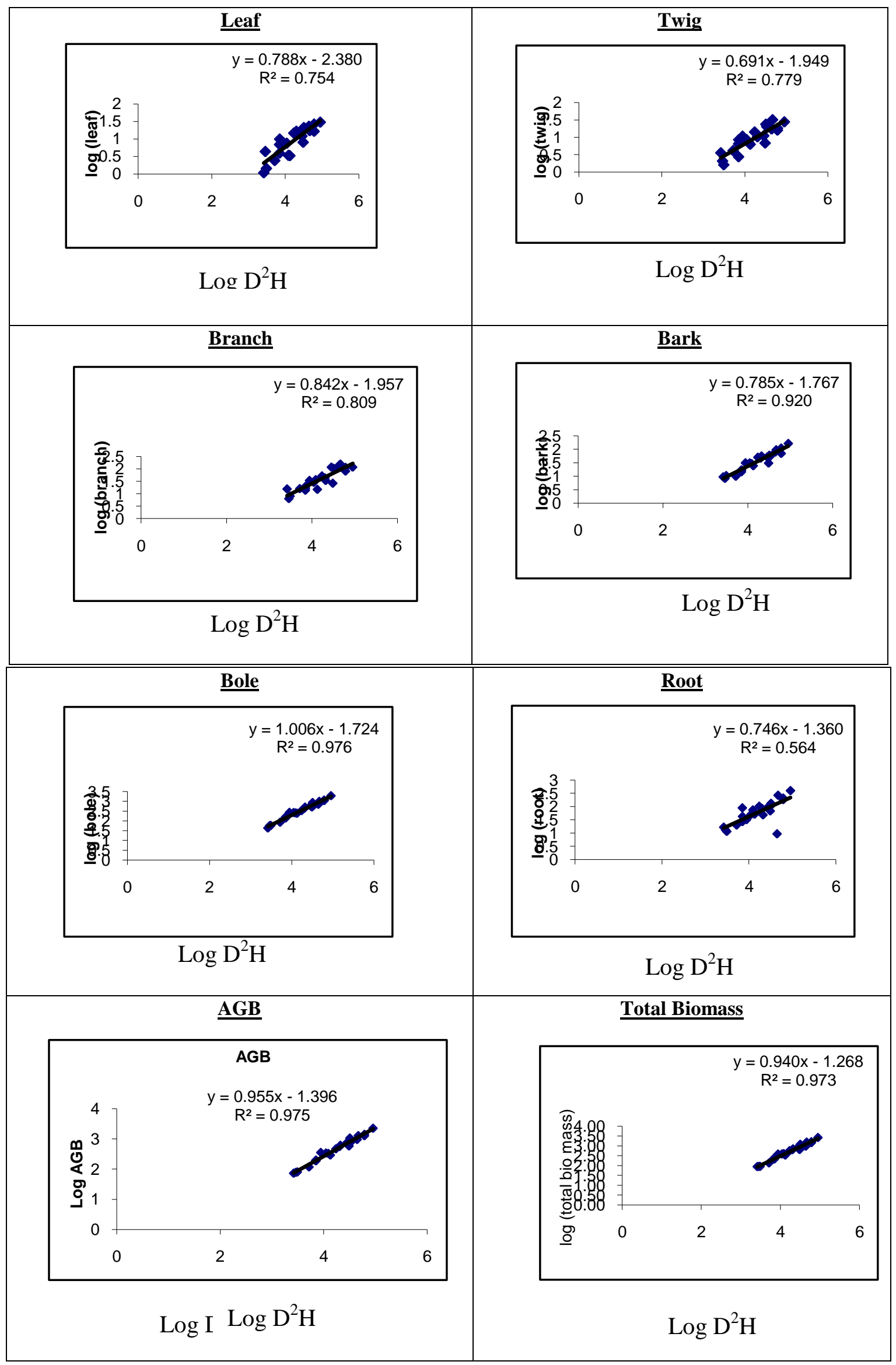

Fig 2.Relationship between $D^{2} \mathbf{H}$ and different tree components of Eucalyptus.

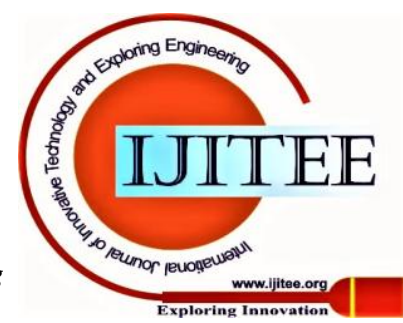


There has been controversy on effects of Eucalyptus plantations in India and elsewhere. There are lots of researches on various aspects of this species particularly in India (Bhatia 1984, George 1984, Pal and Raturi 1984, Gupta and Raturi 1984, Gurumurtyetel. 1984, Poore and Fries 1985, Sharma and Negi 1985, Kapoor and Dogra 1987, Pandeetal. 1987, Negi and Sharma 1987, Rawat and Rawat 1990, Kushalappa 1991, Singhal and Rawat 1991, Tandonetal. 1993, Rawat 1996 \& Shiva and Bandopadhyay 1984) a few to be cited here.

Negi (1984) has compared biomass/ productivity of manmade (E. hybrid) and natural forest of Sal (Shorearobusta) and concluded that man-made forests are highly productive as compared to natural forests. Gurumurtyet al. (1984) studied the biomass production and energy conversion efficiency by Eucalyptus hybrid at different ages (ranging from 12 to 36 months) in Gujarat (Density 5587 plants ha $^{-1}$ ). The total biomass production ranged from $5 \mathrm{t} \mathrm{ha}^{-1}$ (12 months) to $66 \mathrm{t} \mathrm{ha}^{-1}$ (36 months). Extensive studies on biomass and productivity of Eucalyptus hybrid plantations grown in Uttar Pradesh were carried out by George (1977).

About 24 plantations of different age groups of Eucalyptus hybrid grown in different agroclimatic regions were studied for their biomass and productivity and the maximum biomass obtained was $358 \mathrm{t} \mathrm{ha}^{-1}$ (age 12 years, density 1335 trees $^{-1}$ ) with an average annual production of $21.5 \mathrm{t} \mathrm{ha}^{-1} \mathrm{yr}^{-1}$ and $16.1 \mathrm{~kg}$ tree $\mathrm{yr}^{-1}$. Biomass and productivity for a range of plantations of different age groups and few plantations of same age 9 and 10 years grown at different agroclimatic regions of Uttar Pradesh are compared with present study in the table :-

Table 4. Biomass and Productivity of different age group plantations of Eucalyptus hybrid in different agro climatic regions

\begin{tabular}{|c|c|c|c|c|}
\hline $\begin{array}{l}\text { Age } \\
(\text { yrs })\end{array}$ & $\begin{array}{c}\text { Density } \\
\text { (trees } \\
\left.\text { ha }^{-1}\right)\end{array}$ & $\begin{array}{c}\text { Biomass } \\
\left(\mathrm{t} \mathrm{ha}^{-1}\right)\end{array}$ & $\begin{array}{c}\text { Productivity } \\
\left(\mathrm{t} \mathrm{ha}^{-1} \mathrm{yr}^{-1}\right)\end{array}$ & $\begin{array}{c}\text { Productivity } \\
\left(\begin{array}{c}\mathrm{kg} \mathrm{tree}^{-1} \mathrm{yr}^{-} \\
\mathbf{1}^{-}\end{array}\right.\end{array}$ \\
\hline \multicolumn{5}{|c|}{ In U.P(Tewari, 1992) } \\
\hline 5 & 1167 & 57 & 11.4 & 9.7 \\
\hline 6 & 1482 & 101 & 16.8 & 11.4 \\
\hline 7 & 1399 & 99 & 14.1 & 10.1 \\
\hline 8 & 764 & 116 & 14.5 & 19.0 \\
\hline 9 & 1289 & 122 & 13.6 & 10.5 \\
\hline 10 & 1023 & 137 & 13.7 & 13.4 \\
\hline 11 & 1048 & 142 & 12.9 & 12.3 \\
\hline 12 & 1335 & 258 & 21.5 & 16.1 \\
\hline 13 & 860 & 123 & 9.5 & 11.0 \\
\hline \multicolumn{5}{|c|}{ In Punjab(Present study) } \\
\hline 18 & $609-740$ & $\begin{array}{c}206.88- \\
335.76 \\
\end{array}$ & $11.49-18.65$ & $5.06-42.0$ \\
\hline 28 & 560 & 421.03 & 15.0 & $4.88-51.75$ \\
\hline
\end{tabular}

Prediction equations have been worked out on the basis of 17 trees felled for Eucalyptus hybrid for different tree components on the basis of diameter and height $\left(D^{2} H\right)$ which was found to be best suited as depended variable over $\mathrm{D} \& \mathrm{D}^{2}$ as can be seen in the Table 6 . The correlation coefficient $\left(r^{2}\right)$ values of all the tree components are significant where as these values for AGB, BGB and total biomass is highly significant. These equations are validated by comparing the predicted values of total biomass of overall average 6 trees felled with their actual / calculated biomass (Table 7).

As is clear from the table the biomass of lower diameters have very less differences as compared to higher diameters. The differences of predicted and actual biomass ranged from 6.8 to $38.5 \%$ for 5 trees representing mean diameters (13.60 to $35 \mathrm{~cm}$ ) of different diameter classes. 5 trees have shown the lesser percentage differences in (6.82-29.5). Only one tree with mean diameter of 28.80 has shown difference of more than $30 \%$. Generally differences between predicted and actual biomass in percentages of 10-30 is acceptable.

Prediction graphs have been plotted showing relationship of $\mathrm{D}^{2} \mathrm{H}$ to different tree components as shown in Fig 1 . These graphs are plotted on the basis of total 17 trees felled. The Fig 1.clearly show the linear relationship between both the parameters, which confirms the significant correlation in them. Prediction equations, thus, worked are given in the Table 7. and can be used as reference for estimation of biomass of $E$. hybrid of Punjab.

Biomass studies are essential to estimate the net primary productivity, understand the nutrient dynamics, organic and energy transfers, predicting the effects of tree utilization, management procedures or other disturbances on the productivity and stability of forest stands. These studies are of special interest to the grower as they help to judge the performance of the species in terms of total biological production and also to assess the nutrient drain on tree harvesting of the species for commercial purposes on the total biomass. The increase in nutrient content of standing crop with stand age has direct bearing on the total biomass of the stand.

There has been a marked increase in the number of studies on forest biomass during the past decades with the realisation that total organic production is important instead of considering the forest a production system of stem wood. This is probably due to increasing pressure placed on forests by the community for different forest products, search for renewable source of raw materials etc. In addition to the productive role, the growing concern of well being of forest ecosystems has resulted in the appearance of numerous publications on forest biomass throughout the world. For such studies it is essential to make the diameter classes more 
Development of Prediction Regression Equations for Biomass Estimation in Eucalyptus Forest Plantations in the Punjab State of India

carefully, which could cover more trees per diameter class. a few numbers in the plot should be excluded.

The trees of very small and very high diameter having only

Table 5. Regression Equations for Eucalyptus hybrid on the basis of total 17 trees felled

\begin{tabular}{|c|c|c|c|c|}
\hline Dependent Variable & $\begin{array}{c}\text { Correlation } \\
\text { coefficient } \\
\mathrm{r} 2\end{array}$ & $\begin{array}{c}\text { Regression } \\
\text { Equations }\end{array}$ & (a) & (b) \\
\hline Leaf & 0.747 & $\mathrm{Y}=0.7676 \mathrm{X}-2.2946$ & 0.7676 & 2.2946 \\
\hline Twig & 0.828 & $\mathrm{Y}=0.6768 \mathrm{X}-1.8804$ & 0.6768 & 1.8804 \\
\hline Branch & 0.8442 & $\mathrm{Y}=0.8625 \mathrm{X}-2.0245$ & 0.8625 & 2.0245 \\
\hline Bark & 0.9617 & $\mathrm{Y}=0.8327 \mathrm{X}-1.9716$ & 0.8327 & 1.9716 \\
\hline Bole & 0.9871 & $\mathrm{Y}=1.027 \mathrm{X}-1.8234$ & 1.027 & 1.8234 \\
\hline Above Ground Biomass & 0.9757 & $\mathrm{Y}=0.9555 \mathrm{X}-1.3968$ & 0.9555 & 1.3968 \\
\hline Root Biomass & 0.5113 & $\mathrm{Y}=0.7178 \mathrm{X}-1.2111$ & 0.7178 & 1.2111 \\
\hline Total Tree Biomass & 0.983 & $\mathrm{Y}=0.9544 \mathrm{X}-1.3301$ & 0.9544 & 1.3301 \\
\hline
\end{tabular}

Table 6. Comparison of total biomass of average 6 Eucalyptus trees felled for validation of prediction equations of Table 9.

\begin{tabular}{|c|c|c|c|c|c|}
\hline $\begin{array}{c}\text { Tree No. } \\
*\end{array}$ & $\begin{array}{c}\text { Dia. } \\
(\mathrm{cm})\end{array}$ & $\begin{array}{c}\text { Height } \\
(\mathrm{m})\end{array}$ & $\begin{array}{c}\text { Predicted Biomass } \\
\left(\mathrm{kg} \mathrm{tre}^{-1}\right)\end{array}$ & $\begin{array}{c}\text { Actual Biomass } \\
\left(\mathrm{kg} \mathrm{tree}^{-1}\right)\end{array}$ & \% difference \\
\hline 1 & 19.00 & 24.30 & 271.15 & 385.05 & 29.58 \\
\hline 6 & 28.80 & 37.10 & 898.25 & 648.22 & 38.57 \\
\hline 8 & 13.60 & 16.70 & 100.13 & 91.04 & 9.98 \\
\hline 13 & 26.80 & 29.20 & 581.42 & 701.89 & 17.16 \\
\hline 17 & 21.50 & 23.90 & 337.91 & 388.07 & 6.8 \\
\hline
\end{tabular}

* Tree no's of Table $1 / 2$

Table 7.Best Suited Predicted equations developed for biomass estimation of Eucalyptus hybrid trees on the basis of total 17 trees felled.

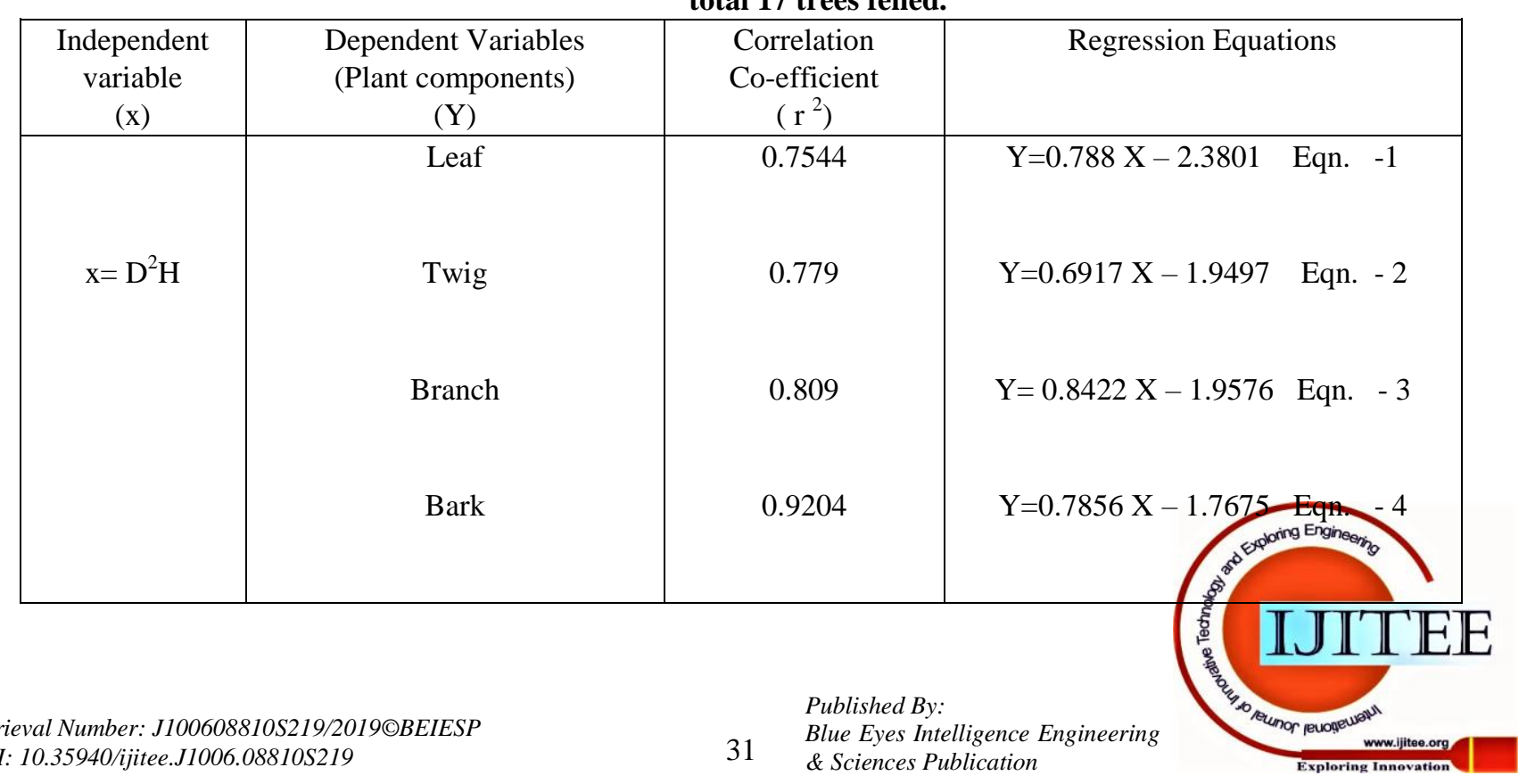




\begin{tabular}{|c|c|c|c|}
\hline Bole & 0.9766 & $\mathrm{Y}=1.0061 \mathrm{X}-1.7249$ Eqn. -5 \\
Above Ground Biomass & 0.9757 & $\mathrm{Y}=0.9555 \mathrm{X}-1.3968$ & Eqn. -6 \\
Root Biomass & 0.5648 & $\mathrm{Y}=0.7463 \mathrm{X}-1.3607 \quad$ Eqn. -7 \\
Total Tree Biomass & 0.9731 & $\mathrm{Y}=0.9402 \mathrm{X}-1.2681$ Eqn. -8 \\
\hline
\end{tabular}

\section{REFERENCES}

1. Art, H. W. and P. L. Marks (1971).A Summary table of biomass and net primary production in forest ecosystems of the world. In: Forest Biomass Studies (ed.Young HE). College of Life Sciences and Agricultural Experiment Station. Univ. of Maine, USA.

2. Bhatia, C. L. (1984). Eucalyptus in India- Its status and research needs. Indian Forester, 110(2): 91-96.

3. Dogra, A.S. and AnoopUpadhyaya (2005).Site index equation for Eucalyptus hybrid in Punjab.Indian Forester 131(4):487-498

4. Dogra, A.S. and S. S. Sandhu (1984).Role of Eucalyptus in the economy of Punjab.InEucalyptus in India past, present and future. Kerala Forest Institute Kerala

5. George, M (1984). Nutrients removal from Eucalyptus plantations by harvesting wood.Indian Forester, 110(1): 61-67.

6. George, M. (1977).Organic Productivity and Nutrient Cycling in Eucalyptus hybrid Plantations.Ph.D.Thesis, Meerut University, Meerut, India.

7. Gupta, A. C. and D. P. Raturi (1984): Distribution of organic matter and nutrient contents in anEucalyptushybrid plantation on lateritic soils in West Bengal. Indian Forester, 110 (2): 122-128.

8. Gurumurty, K., M. M. Kimothi, D. P. Raturi and J. S. Rawat (1984).Biomass production and energy conservation efficiency by Eucalyptus in energy plantations.Indian Forester, 110(2): 150-170.

9. Kapur, S. K. and A. S. Dogra (1987).Provenance trial of Eucalyptus camaldulensis in Punjab.Indian Forester, 113(7):471-475.

10. Kushalappa, K. A. (1993). Productivity Studies in Mysore Gum.(Eucalyptus hybrid).Associated Publishing Co. New Delhi. India.

11. Negi J.D.S. and D. C. Sharma.(1987). Biomass estimation of two Eucalyptus species by regression methods.IndianForester, 113(3): $180-183$.

12. Negi, J.D.S (1984). Biological productivity and cycling of nutrients in managed and man-made ecosystems.Ph. D. Thesis, Garhwal Univ. Srinagar Garhwal, UP.pp 161

13. Pal, M. P., and D. P. Raturi (1991). Growth, biomass production and dry matter distribution pattern of Eucalyptus hybrid grown in an energy plantation Indian Forester 117(3): 187-192.

14. Pande, M. C., Tandon,V. N. and H.S. Rawat (1987). Organic matter production and distribution of nutrients in Eucalyptus hybrid plantation ecosystems in Karnataka.Indian Forester, 113 (11): 713 724.

15. Poore, M.E.D and C. Fries (1985). The ecological effects of Eucalyptus.Natraj publishers Dehra Dun.

16. Qureshi, I. M. (1966).The so-called Eucalyptus hybrid of Mysore origin.Indian Forester, 92(4): 213-217.

17. Rawat, Laxmi and V. R. S. Rawat (1990).BhartiyaParivesh Mein EucalyptusaurParyavaran- Kutch VaigyanikTathya.VanAvamPrakriti, 1 (1): 1-6 (Hindi). Eucalypts and environment in Indian context Some scientific facts.

18. Rawat, V. R. S. (1996). Effects of climatic factor on growth of Eucalyptustereticornisin India. M. Sc. Tropical Forestry Thesis submitted in George August University Goettingen, Germany pp 113

19. Sehgal, J. L., D. K. Mandal and S. Vadivelu (1990).Agro-Ecological Regions of India.Technical Bulletin. NBSS Publ. 24. National Bureau of Soil Survey and Land Use Planning (ICAR) Nagpur, India. 73pp.

20. Sharma, S. C. and J. D. S. Negi (1985).Eucalyptus dilemma- A Classification thereof.Indian Forester, 111(12): 1139-1150.
21. Shiva V. and J. Bandopadhyay (1984).Ecological Audit of EucalyptusCultivation.English Book Depot, Dehradun. India.

22. Singh, R. P. and V. K .Sharma (1976). Biomass estimation in five different aged plantations of Eucalyptus tereticornis Smith in western U.P. OSLO Biomass Studies. Univ. of Maine, Orono, USA, 143-161.

23. Singhal, R.M. and J.K. Rawat (1991). Effects of growing Eucalyptus (eds). ICFRE -2/ FRI Publication.

24. Tandon, V.N., J.K. Rawat and Rajinder Singh (1993). Biomass production and mineral cycling in plantation ecosystem of Eucalyptus hybrid in Haryana I Biomass production and its distribution Indian Forester, 119(3): 232-237.

25. Tewari, D. N. (1992). Monograph oh EucalyptusRohini. Printer \& Publishers Nasville Rd. Dehra Dun.

26. Momolli, D., Schumacher, M., Ludvichak, A., \& Araújo, E. (2019) Modeling and Biomass Quantification in Eucalyptus saligna Smith Stand at the End Rotation in the South of Brazil. Journal of Experimental Agriculture International, 33(3), 1-10. https://doi.org/10.9734/jeai/2019/v33i330146 